\title{
Work-life balance policies: Challenges and benefits associated with implementing flexitime
}

\author{
Authors: \\ Caroline Downes ${ }^{1}$ \\ Eileen Koekemoer ${ }^{1}$ \\ Affiliations: \\ ${ }^{1}$ School of Human Resource \\ Management, Faculty of \\ Economic and Management \\ Sciences, North-West \\ University, South Africa \\ Correspondence to: \\ Eileen Koekemoer \\ Email: \\ eileen.koekemoer@nwu.ac.za \\ Postal address: \\ PO Box 19087, Noordbrug, \\ Potchefstroom, South Africa \\ Dates: \\ Received: 27 Apr. 2011 \\ Accepted: 28 June 2011 \\ Published: 20 Oct. 2011 \\ How to cite this article: \\ Downes, C., \& Koekemoer, \\ E. (2011). Work-life balance \\ policies: Challenges and \\ benefits associated with \\ implementing flexitime. SA \\ Journal of Human Resource \\ Management/SA Tydskrif vir \\ Menslikehulpbronbestuur, \\ 9(1), Art. \#382, 13 pages. \\ doi:10.4102/sajhrm.v9i1.382

\section{Notes:} \\ Caroline Downes conducted \\ this research as part of her \\ masters degree that she \\ completed at the North-West \\ University.
}

C 2011. The Authors. Licensee: AOSIS OpenJournals. This work is licensed under the Creative Commons Attribution License.
Orientation: Helping employees to balance their work and family lives is a business imperative. Work-life balance policies (like flexitime) aim to support employees to do so. However, implementing these policies is problematic.

Research purpose: The aim of this article is to report on the challenges and benefits associated with implementing flexitime as a work-life balance policy.

Motivation for the study: Organisations must develop and implement work-life balance policies. This requires human resource practitioners to investigate and understand experiences and perceptions about the challenges and benefits of flexitime.

Research design, approach and method: The researcher used a qualitative research design with an exploratory approach. She drew a nonprobability purposive and voluntary sample $(n=15)$ from the financial sector. She used semi-structured in-depth interviews to collect the data and conducted content analyses to analyse and interpret them.

Main findings: The researcher extracted four main themes (individual and general challenges, the aspects organisations need to implement flexitime effectively and the benefits that would follow its implementation) from the data. Its benefits vary from work-life balance to employee loyalty and commitment. Some challenges are maintaining productivity, a shortage of critical resources and understanding flexitime.

Practical/managerial implications: The research identified requirements that human resource practitioners should attend to in order to ensure that organisations use flexitime more effectively.

Contribution/value-add: The researcher obtained unique findings about the minimum requirements for implementing flexitime effectively. They could assist organisations to address the challenges that employees face.

\section{Introduction}

\section{Key focus of the study}

Organisations have recently experienced more and more competitive pressure to perform faster and better and to be more cost-effective (Blyton, Blunsdon, Reed \& Datmalchian, 2006; Duxbury \& Higgins, 2003).

Consequently, there has been a breakdown of the traditional working contract and the concept of lifetime employment has become a notion of the past (Galinsky, Bond \& Hill, 2004; Halpern, 2005). Organisations must now accommodate a variety of supply and demand factors, one of which is the demand for a secure, flexible and low-cost labour force. The recent changes in the nature of work, along with the introduction of new technologies (cellphones, email and other means of electronic communication) have led to many employees struggling to balance roles in their work and personal lives (Hayman, 2009; Hobsor, Delunas \& Kelsic, 2001).

As a result, organisations and employees are becoming increasingly aware of the potential benefits of work-life balance (WLB) and associated WLB policies.

The present study aims to explore the perceived challenges and benefits associated with implementing WLB policies, especially that of flexitime.

\section{Background to the study}

Work-life balance is an important and critical issue in the 21st century. However, human resource practitioners only recently began to see WLB as a business issue that has benefits for both employees and employers (Clutterbuck, 2003). 
Research that supports the benefits of WLB for organisations is substantial. It highlights a positive, although indirect, influence on organisational profit (Michie \& Williams, 2003; Morgan, 2009). Organisations and employees are becoming increasingly aware of the potential benefits of employee WLB. Some of them include employee satisfaction and well-being; reduced absenteeism and turnover; successful recruitment and retention; increased productivity; and customer satisfaction (Mayberry, 2006; Morgan, 2009; White, Hill, McGovern, Mills \& Smeaton, 2003). A Roffey Park Institute (2004) study found that $38 \%$ of a sample of employees would consider leaving their current employer to gain a better WLB, even if it meant reduced pay. Mayberry (2006) also states that organisations that invest heavily in WLB report lower employee turnover.

Consequently, WLB is one of the top employee concerns of today and is a frequent topic of discussion during recruitment interviews (Clutterbuck, 2003). In the 2003 Best Company to Work for Survey, 23 companies reported employee WLB as a key aspect of their retention strategies (Dex, 2004). Furthermore, in a 2008 study at Johnson and Johnson, employees who used WLB policies took only half as much sick leave as those who did not (Morgan, 2009).

With such important organisational advantages, it is not surprising that the existence and use of WLB policies have become increasingly prevalent globally (Doherty, 2004; Ferber, O’Farrell \& Allen, 1991; Kossek \& Ozeki, 1998; Reynolds, 1999; Sanichar, 2004). In addition, a few multinational organisations in South Africa have adopted these policies (Appiah-Mfodwa, Horwitz, Kieswetter, King \& Solai, 2000; Mageni \& Slabbert, 2005).

\section{Research purpose}

Some studies do give information about the use of flexitime in South Africa. However, there is little information about its implementation and value as a WLB policy and contributor to WLB for the South African employee. In addition, the associated challenges and benefits of this policy seem to be lacking in previous research.

Therefore, the aim of this article is to report on the challenges and benefits associated with implementing flexitime as a WLB policy in a South African organisation.

\section{Trends from the research literature}

According to Lewis and Cooper (2005), flexitime (or 'flexible working hours') is one of the most commonly used WLB policies and its use is increasing steadily.

Flexitime supports significantly higher levels of WLB than do traditional, fixed-hour working schedules (Hayman, 2009). According to research from the Families and Work Institute, employees with greater control over work schedules are more likely to show increased engagement, retention, job satisfaction and overall well-being (Powers, 2004). Various additional benefits for organisations to implement flexitime successfully include savings on overtime and other premium employee payments; improved delivery time and response to client and work demands; better employee adaptability to workloads; increased employee motivation; and reduced tardiness and absenteeism (Horwitz, Kieswetter, King \& Solai, 2000).

\section{The potential value-add of the study}

Because of the potential obstacles or challenges that human resource practitioners usually face when they implement WLB policies, employers should consider flexitime carefully. How organisations implement WLB policies determines their success (Mageni \& Slabbert, 2005).

Therefore, organisations need to develop, implement and frequently monitor WLB policies like flexitime (Clutterbuck, 2003; Dancaster, 2006; Duxbury \& Higgins, 2003; Horwitz et al., 2000). Monitoring and implementing these policies means that human resource practitioners must investigate and understand the experiences, views and perceptions of all stakeholders, especially those of employees, about the challenges and benefits of flexitime and its implementation.

Information about the possible challenges and benefits associated with implementing policies is critical for organisations. Without this information, they are likely to develop and implement policies that they have not tailored to the needs and requirements of employees. Consequently, organisations might fail to achieve the benefits they expect (Clutterbuck, 2003; Mageni \& Slabbert, 2005; Mayberry, 2006).

In South Africa, most organisations are not sufficiently aware of employee perspectives about how they implement their WLB policies, especially flexitime. The researcher believes that this article will give South African organisations the information they need to develop and implement flexitime policies. It could benefit both employees and employers.

\section{Literature review}

\section{Work-life balance policies and flexitime}

Given the considerable influence of the absence of WLB on employees and organisations, initiatives aimed at supporting employees with WLB problems have become more popular and commonplace in organisations (Cooke, Zeytinoglu \& Mann, 2009).

WLB policies improve the autonomy of workers in coordinating and integrating the work and nonwork areas of their lives (Felstead, Jewson, Phizacklea \& Walters, 2002).

Mayberry (2006) has identified over 100 variations of WLB policies. Amongst the alternatives that organisations offer are on-site or subsidised child and/or elder care, flexible working schedules, job sharing and employee assistance programmes (Dalcos \& Daley, 2009; Hobsor et al., 2001). 
Although these alternatives vary considerably, according to Dex (2004), most WLB policies fall into five categories:

1. flexitime work schedules

2. flexiplace or telecommuting

3. job-sharing

4. part-time flexiplace

5. sabbaticals or career breaks.

Recently, international studies have shown that there is a greater focus on introducing and implementing workplace flexibility (flexitime) compared to other WLB initiatives (Carlson, Grywacz \& Kacmar, 2010).

Flexitime is an alternative or flexible working schedule. It is central to research on WLB. It is also a key strategy that policy makers use to assist employees in today's global economy (Hill et al., 2010). The National Study of Employers showed a significant increase, between 1998 and 2009, in the number of employers that offer flexitime (Carlson et al., 2010). According to Hill et al. (2010), flexitime assists employees to manage their work and family responsibilities by allowing them to reduce work-family conflict and to improve functioning and performance at work and at home.

The literature calls flexitime a variety of flexible work schedules. All of them offer employees choices about the start and end of working hours. All employees must work a specific number of hours per week or month. However, they may vary their hours of work within limits (Robbins, Ordendaal \& Roodt, 2004).

Similarly, according to Dalcos and Daley (2009), flexitime allows employees to choose when, where and for how long they engage in work-related tasks. Flexitime usually means that each working day has a core of six hours surrounded by a 'flexibility band' in which employees may exercise their discretion (Robbins et al., 2004). Therefore, one employee may work between 07:00 and 15:00 whereas another may choose to work between 08:00 and 16:00. The core hours are between 09:00 and 15:00 (Lewis \& Cooper, 2005).

However, flexitime is an umbrella concept or approach. This is clear from the different ways and varying degrees that organisations offer flexibility (Horwitz et al., 2000). According to Lewis and Cooper (2005), variations of this policy often include different starting and finishing times for each day, the length and timing of lunch breaks, the length of the working day and compressed workweeks. A compressed workweek allows for varying the length of the week so that employees may work for only three days a week whilst still working the total number of hours required for a working week (Robbins et al., 2004).

\section{Implementing flexitime}

Despite the potential benefits of flexitime, its implementation has been problematic (Clutterbuck, 2003; Mayberry, 2006;
Powers, 2004). Some of the problems the literature has raised include (Akyeampong, 1993; CIPD Research Report, 2000; McDonald, Bradley \& Brown, 2008):

- the different ways organisations manage flexitime

- difficulties with implementing flexitime in teams and work groups

- the absence of communication and education about these policies

- the possible stigma or career penalties associated with using flexitime.

Furthermore, managers and/or organisational leaders may discourage flexitime implicitly or explicitly because of their reluctance to relinquish control (Dancaster, 2006).

International research has covered WLB and WLB policies, like flexitime, well (Clutterbuck, 2003; Hill, Erickson, Holmes \& Ferris, 2010; Richman, Civian, Shannon, Hill \& Brennan, 2008). However, there is little research on WLB policies, especially flexitime, in the South African working context (Dancaster, 2006). There have been some work-family balance studies in South Africa. However, most of these studies were cross-sectional quantitative studies that focused more on the conceptualisation, measurement and associated outcomes of WLB (Koekemoer \& Mostert, 2006; Koekemoer, Mostert \& Rothmann, 2010; Koekemoer \& Mostert, 2010b; Marais, Mostert, Geurts \& Taris, 2009; Mostert, Cronjé \& Pienaar, 2006; Mostert \& Rathbone, 2007; Patel, Govender, Paruk \& Ramgoon, 2006; Pieterse \& Mostert, 2005; Rost \& Mostert, 2007).

Until the present, South African research on flexitime has focused on labour market flexibility (Horwitz, Allan, Brosnan \& Walsh, 2000) and atypical work (Greef \& Nel, 2003) and neglected WLB. Consequently, issues surrounding WLB policies and flexitime are severely underrepresented (Dancaster, 2006). The available research on flexitime is limited. It covers the relevance of flexitime to the South African workplace, the personal consequences of flexitime for White working mothers, legislation and flexible working arrangements (Barling \& Barunbrug, 1984; Dancaster, 2006; Mageni \& Slabbert, 2005).

The next section discusses the research design and methodology the researcher used in this study. She used a qualitative approach to explore the implementation of flexitime. She discusses the results. She also presents and discusses various themes about implementing flexitime.

\section{Research design \\ Research approach}

The researcher used a qualitative research design and an exploratory approach to explore and describe employees' experiences of the implementation of flexitime. By applying the methodology of the post-positivism paradigm, researchers can acquire information in more natural settings by collecting more situational information and determining 
the meanings and purposes that people ascribe to their actions (Guba \& Lincoln, 1994).

In this research, a qualitative approach was especially beneficial because it allowed employees to describe what was meaningful or important to them about flexitime in their own words rather than restricting them to predetermined categories.

Qualitative research, using an exploratory or phenomenological approach, allows researchers to understand and present personal points of view that participants often conceal (Hammersley, 1998). An interpretative phenomenological approach aims at gaining a better understanding of the nature and quality of the phenomena (flexitime in this study) as they occur (Willig, 2008).

\section{Research strategy}

The research strategy the researcher used in this research was to analyse the employer's implementation of flexitime in the organisation through interviews where the employee was the unit of analysis. She interviewed 15 employees to gain more insight into, and detailed information about, how the organisation implements flexitime.

\section{Research method}

\section{Research setting}

During interviews, it is important to note the interaction between researchers and participants in a particular context or setting (Terre Blanch, Durrheim \& Painter, 2006). With the importance of the setting in mind, the researcher used a private interview room at the Johannesburg offices of the organisation.

The organisation the researcher used for this research was an international financial institution. Its employees worked at various levels of management. She was careful to ensure that the interview room was comfortable, temperate and quiet, and located at a sufficient distance from other employees to ensure privacy. To reduce disturbances, the researcher placed a 'do not disturb' sign on the door. Because the validity and success of the research depended on the participants being at ease with the research process (Hesse-Biber \& Leavy, 2004), the researcher introduced herself in a warm and friendly manner, detailed the context of the interview and emphasised its purpose.

\section{Entrée and establishing the researcher's roles}

The research field consisted of an international auditing and consulting organisation located in Johannesburg that offers its employees access to, and use of, flexitime as a WLB policy.

It is critically important to establish entry into the research field before data collection commences (De Vos, Strydom, Fouche \& Delport, 2005). In order to establish the roles of the researcher, the organisation and participants, the researcher held meetings with the managers of the organisation, before the research commenced, to discuss the aim of the research and to obtain written permission for it.

The researcher was an external researcher and not an employee of the organisation. She approached the organisation for permission to conduct the research at the organisation.

In order to conduct the research as unobtrusively as possible and to ensure that the participants did not see the researcher as a threatening intruder (De Vos et al., 2005), the organisation appointed an employee from the organisation to introduce the participants to the researcher and to arrange suitable interview dates and times. This person acted as inter-mediator.

The role of the inter-mediator was to identify employees who were willing to participate in the research and to provide the researcher with the necessary contact details and other biographical information. This happened after the researcher obtained permission to conduct the research. The intermediator arranged for the interviews and the researcher only attended or visited the organisation on the dates and times of the interviews.

During qualitative research, researchers act as research tools and encourage the participants to discuss their perspectives, experiences, feelings and thoughts openly. Consequently, researchers have direct influences on the quality of the data (Ritchie \& Lewis, 2005). Therefore, the researcher in this study attended qualitative training that emphasised interview skills and communication techniques. Interview training has a major effect on the quality of the data and is especially necessary when researchers need in-depth and detailed data (Lewis-Beck, Bryman \& Liao, 2004).

In an effort to control for interviewer distortion, it was critical for the researcher to be constantly aware of her personal views and potential bias and of how her subjectivity could influence the objectivity and neutrality of the findings (Terre Blanche et al., 2006).

Reflection, in the form of critical self-examination, happened during the interview process. The researcher took time to reflect on her interview performance and influence after each interview.

To assist with this, the researcher used a co-researcher to discuss any concerns that the she had. The co-researcher assisted with developing the interview schedule, provided support during data collection and reviewed the quality of the information.

The researcher explained the use of tape recorders and asked the participants for permission to use one before the interviews began. During this research, she applied five basic ethical considerations to the treatment of participants. These were informed consent, no deception, the right to withdraw, 
debriefing and confidentiality (Willig, 2008). She discussed all these aspects with the participants before they decided to participate in the research and emphasised them again during the interviews.

\section{Sampling}

The researcher drew a nonprobability purposive and voluntary sample of 15 employees from the research field, an international auditing and consulting organisation in Johannesburg. Besides selecting the research participants in a non-random manner, she included criteria to determine which employees could form part of the research sample.

These criteria required that employees:

- should have access to the flexitime that the organisation offered

- be willing to participate in the research and give their written consent after the researcher informed them about the purpose and procedures of the research

- be willing to be interviewed by the researcher

- be prepared to have their interviews tape recorded.

The researcher determined the sample size according to the number of employees who were accessible and willing to participate. In this sample, most participants were women (60\%), English-speaking (53.30\%) and between the ages of 30 and 39 (66.70\%). Although most participants had children (66.7\%), some participants had no children (33.30\%). More than half of the sample was married or living with a partner and their children still lived at home (53.30\%). Although all of the participants indicated that they had a domestic helper to assist with household chores (100\%), very few participants indicated that a nanny or au pair assisted them $(13.30 \%)$ or had a stay-at-home husband $(6.70 \%)$ who looked after the children.

With regard to position at work, the sample had more participants at senior levels, like managerial (33.3\%) and senior managerial levels $(26.7 \%)$. There were only a few participants at partner $(20.00 \%)$ and associate director or director levels $(6.70 \%)$.

The interviews continued until the data was saturated (Terre Blanche et al., 2006).

\section{Data collection methods}

The researcher collected the data using semi-structured individual interviews. A 'semi-structured interview' is a method of collecting data where a flexible interview schedule guides a single interviewer who uses active listening and probing to allow for in-depth detail and understanding (Forrester, 2010). Using the interpretive approach, a semistructured interview allows the researcher to gather data and study the phenomenon from the perspectives of the participants, probing further when unexpected issues emerge (Neuman, 2003).

The researcher developed and evaluated the interview schedule before the interviews. Two external experts in qualitative research and the field of work-life balance research evaluated and helped to develop the interview schedule. The schedule asked the participants three standard questions after the preamble:

Your organisation offers you flexitime and you have access to it.

1. Please indicate whether you use flexitime or not.

2. Please describe what you perceive as challenges when it comes to using the flexitime your organisation offers.

3. What do you perceive as the benefits of using the flexitime your organisation offers?

The researcher also used communication techniques like minimal verbal response, paraphrasing, reflection, clarifying and summarising to encourage participants to elaborate on their feelings, thoughts, experiences and perspectives (Neuman, 2003).

In addition to the verbal information the researcher collected during the interviews, she made observation notes (or field notes) immediately after each interview. She categorised these notes as methodological or personal (Hesse-Biber \& Leavy, 2004). Her methodological notes referred to possible influences on the research process like the environment, comfort and interruptions (Bester, 2010). The personal notes contained the researcher's own experiences, like her emotional and physiological state as well as her experience of the participants (Bester, 2010). Therefore, these observation notes provided a written account of what the researcher saw, heard, experienced and thought during the interviews and could contribute more depth and detail to the research findings.

\section{Recording of data}

With the permission of the participants, the researcher tape recorded the interviews and transcribed them verbatim. In addition, she made detailed observation notes after each interview.

In order to ensure confidentiality, the researcher labelled her observation notes, transcriptions and tapes using alphabetical coding according to the interview plan that only the researcher knew. For example, she coded interview one as interview A and interview two as interview B.

The researcher stored the observation notes, the transcriptions and tapes safely to ensure that data could not expose or exploit the participants (Burns \& Grove, 1997). Creswell (2003) also emphasised protecting the data as an important research issue because data should be protected from loss, destruction and unauthorised access.

Although the participants had given their written consent, the researcher assured them that they could withdraw from the research at any time should they wish to. Throughout the research, the researcher upheld and respected the participants' right to privacy, anonymity, fair treatment and to protection from discomfort and harm (Neuman, 2003). 


\section{Data analysis}

During the data analysis process, the researcher analysed the verbatim transcripts using content analysis and an interpretative phenomenological approach.

Content analysis is a systematic technique that gathers and compresses large bodies of text into specific and identifiable content categories (Hesse-Biber \& Leavy, 2004). This method of qualitative analysis was appropriate for this research because it focuses on, and considers, both content and the contextual meaning of the text. It assisted the researcher to make replicable and valid inferences (Hsieh \& Shannon, 2005). Analysing qualitative data using an interpretive approach is a process of making sense. It requires researchers to immerse themselves in the data, to make sense of the data and to identify themes. These themes give a recognisable and useful account of the data (Lyons, 2007).

The researcher first read the interview transcripts thoroughly several times. She then divided the participant responses into meaningful units and wrote them as sentences or paragraphs. Finally, she separated all the meaningful units into categories that she identified as major themes.

The co-researcher later reviewed and agreed that these were the themes. Following careful analysis of the major themes, the researcher, with the help of the co-researcher, was able to recognise, explore and summarise the major themes as smaller and comparable subthemes. Although the researcher took comprehensive field notes after each interview, they yielded no significant new meanings or suggested contrasting evidence or findings. According to De Vos et al. (2005), researchers do not necessarily use the observation notes in their final report. However, they can review observation notes and decide if they should include the notes based on their content and the value they add.

\section{Strategies employed to ensure quality data}

Quality data gives a detailed description of the researchers' experience and involvement in the research. They also present the authentic perspectives and context of the research participants (Neuman, 2003).

The researcher upheld the principles of credibility (checking the truth-value of the findings), transferability (ensuring the applicability of the findings), dependability (ensuring the consistency of the findings) and conformability (ensuring neutrality or freedom from bias) to ensure quality data (Appleton, 1995; De Vos et al., 2005; Guba, 1981).

The researcher used six measures to ensure the quality of the data. She:

1. attended pre-pilot interview training to improve her interviewing skills and confidence, followed by pilot interviews to evaluate the interview schedule and to give her interviewing practice

2. described each stage of the research clearly and carefully to explain what she did and why and to ensure that she followed the process exactly and remained neutral throughout the interviews

3. collected comprehensive observation notes after each interview for additional detail, depth and quality of data

4. used an independent co-coder to review the main and subthemes

5. discussed the interpretations of the findings with the participants and peers to ensure truth-value after presenting the findings to the managers of the organisation in a feedback session

6. interacted with the readers to ensure that she presented the material in such a way that the readers felt that the research clarified or increased their understanding of the subject matter (Willig, 2008) through elaborate explanations and/or interpretations of the findings and by providing examples or transcript excerpts.

\section{Reporting}

The researcher used a qualitative reporting style in which she described each of the major themes that emerged from the data separately. She presented and discussed the participants' experiences of each of the major themes. She also offered selected quotations (interview excerpts) to illustrate the typical responses of the participants and the more complex themes that required further explanation. She made minor changes, which involved omitting words from some of the interview excerpts without affecting their meaning, in order to produce a more concise statement that would assist readers to understand it (De Vos et al., 2005).

\section{Reflexivity}

The researcher influences and shapes the research process as a person in qualitative research. This is personal reflexivity (Willig, 2008). It is important because it encourages researchers to reflect on the extent to which the person of the researcher is implicated in the research and its findings. According to Willig (2008), researchers can integrate reflexivity in a report and raise it in context, whenever it is relevant. In this research, the researcher reflected upon the themes that she extracted during the data analyses. She reports on these after the findings that follow.

\section{Findings}

The researcher identified four main themes from the data. The first two themes relate to challenges associated with implementing flexitime. A clear difference emerged from the responses about the specific challenges that employees face about their own use of flexitime and the more general challenges associated with implementing flexitime. The researcher consequently labelled these themes 'individual challenges' and 'general challenges'.

The third theme relates to the requirements for the effective implementation of flexitime, whilst the last theme indicates the benefits of flexitime. 
The researcher describes these four themes in more detail below. She gives associated meanings and explanations to illustrate.

\section{Theme 1: Individual challenges associated with using flexitime}

It was clear from the responses that several issues confronted the participants who used flexitime.

Table 1 presents these individual challenges.

Some participants describe maintaining productivity or performance as more challenging when they work flexitime compared to when they work fixed hours. According to some participants, this challenge is most common when they use flexitime to postpone work because of personal commitments or responsibilities, laziness or poor time management. It then negatively affects achieving deadlines and outputs.

However, other participants admitted to working far longer hours or taking little or no personal or free time because they cannot disengage from work. Therefore, although some participants may work flexibly and maybe not in afternoons, their inability to disengage from work makes it difficult. In addition, they mentioned this inability to disengage because of its negative influence on managing and maintaining personal life and work - instead of spending time with family or friends, some participants continued working.

Some participants highlighted the lack of infrastructure, like connectivity, as one of the main reasons why they preferred not to use alternative working environments because these critical resources are essential to their work.

Here are two examples of participants' comments:

'You end up working longer hours, you actually don't relax ever
because you are constantly working.'

(Participant 6)

'As a single mom I don't have the flexible support at home to just rearrange my hours.'

(Participant 5)

Besides these challenges that employees face, the researcher also identified some general challenges.

\section{Theme 2: General challenges associated with flexitime}

Table 2 presents these general challenges.

According to the participants, one of the major challenges is managing employees' productivity, performance and availability and their perceptions about flexitime. Despite the apparent awareness of flexitime in the organisation, responses revealed a significant lack of knowledge and understanding about its use. Frequent misconceptions related to who may and may not use it and how one should apply to use flexitime.
TABLE 1: Individual challenges associated with using flexitime.

\begin{tabular}{|c|c|}
\hline Subthemes & Associated meaning or explanation \\
\hline $\begin{array}{l}\text { Having to maintain productivity } \\
\text { or performance }\end{array}$ & $\begin{array}{l}\text { - maintaining productivity whilst using flexitime } \\
\text { - mainining deadlines and outputs } \\
\text { to those who work regular hours and do not } \\
\text { use flexitime } \\
\text { - not being able to compare or compete with the } \\
\text { productivity of those who do not use flexitime }\end{array}$ \\
\hline Disengaging from work & $\begin{array}{l}\text { - having difficulty disengaging mentally from } \\
\text { work when participating in nonwork activities } \\
\text { (like working or thinking about work when at } \\
\text { home or participating in nonwork activities) } \\
\text { - constantly working } \\
\text { - working longer and more hours }\end{array}$ \\
\hline $\begin{array}{l}\text { Infrastructure of alternative } \\
\text { work locations }\end{array}$ & $\begin{array}{l}\text { - a lack of critical resources at home (like no } \\
\text { connectivity) } \\
\text { - an unsupportive work environment at home } \\
\text { (like difficulty in working with children present) }\end{array}$ \\
\hline $\begin{array}{l}\text { Managing and maintaining a } \\
\text { balance between personal life } \\
\text { and work }\end{array}$ & $\begin{array}{l}\text { - finding it difficult to balance children or babies } \\
\text { with work or career responsibilities } \\
\text { - mothers who want to be at home and pursue } \\
\text { a career } \\
\text { - maintaining or pursuing personal life and career } \\
\text { goals }\end{array}$ \\
\hline Time management & $\begin{array}{l}\text { - Employees struggle to plan, juggle and meet } \\
\text { work and nonwork demands and responsibilities } \\
\text { successfully when they are participating in both } \\
\text { domains at the same time (like difficulties with } \\
\text { meeting deadlines and tending to personal } \\
\text { responsibilities, like children, all in one day) }\end{array}$ \\
\hline
\end{tabular}

TABLE 2: General challenges associated with using flexitime.

\begin{tabular}{ll}
\hline Subthemes & Associated meaning or explanation \\
\hline Inconsistent understanding or & - poor communication and information on what is \\
knowledge of flexitime & meant by flexitime in the organisation \\
- unclear information about how employees & should use flexitime \\
- unclear information about who qualifies for & flexitime \\
- poor and inconsistent information about & managing employees' flexitime \\
- misconceptions and misunderstandings about & employees' use of flexitime
\end{tabular}

From the responses, it was clear that only a few employees actively discussed flexitime with their managers, possibly because of the negative perceptions surrounding it. Some 
participants said that many employees believe that women, especially mothers, are the only rightful users of flexitime, thus restricting the use of flexitime by other employees. Another general perception the participants held was that if one is not at work one is misusing flexitime and not working. Some employees, who are aware of these perceptions, would therefore restrict their use of flexitime. Moreover, these perceptions pose a greater challenge when managers and directors hold them. They, in turn, may restrict access and use.

Possible misuse of flexitime was a major challenge that participants in managerial positions mentioned. They said they could not ensure whether employees were really working or even with clients when they were not at the office. Many of these participants also highlighted their concern about the lack of a disciplinary process for the misuse and abuse of flexitime they had witnessed. Managers also frequently mentioned that junior employees are likely to misuse flexitime and the challenge this presents for managers to monitor their use of flexitime more closely. Some managers stated that they refused flexitime to junior employees until they had proved their 'professional maturity' and earned the privilege.

The availability of employees (in some cases face-to-face availability) is often an expectation of clients and colleagues who depend on employees for assistance or to complete tasks. This expectation, coupled with the ever-changing demands of the environment, influences employee access and use of flexitime. Some participants said the unavailability of colleagues was a significant challenge and concern, especially when it directly influences their productivity or outputs. The following quotations are examples:

'I don't have a problem with people using flexitime until the point where it impacts negatively on my ability to deliver, then I get voicey about it. I sometimes can't get hold of a person for days because he/she is working from home or "working differently"; it's so frustrating and it affects my ability to deliver.'

(Participant 14)

'If you are working with clients, internal or external, there is this expectation of availability, and not just telephone availability, but faceto-face availability. Some clients get really irritated by us using it.'

(Participant 8)

Employees who face clients and who were not always granted access to flexitime by managers or their departments consistently identified this as a challenge because clients do not understand or support flexitime and become irritated by employees who use it. Here is a comment one made:

'There are directors that don't want flexitime to be used and so they just put a lot of pressure on their staff so they don't use it.'

(Participant 9)

Participants also mentioned aspects of flexitime that relate closely to the challenges. According to the participants, these aspects - if they are present - greatly increase the effective use of flexitime. The participants regarded them as minimum requirements for the effective implementation of flexitime.
The researcher included the aspects that are necessary for flexitime to be effective in theme 3 .

\section{Theme 3: Required aspects for the effective use of flexitime}

These aspects could, in some cases, help to alleviate the challenges mentioned earlier. The participants regarded them as critical for the effective implementation of flexitime.

Table 3 presents them.

Participants often mentioned the need for critical resources, like connectivity and employee face-to-face availability, because they were aware of the importance of continuous communication. They highlighted communication as a critical requirement for planning and managing tasks successfully. The quotation that follows illustrates and explains this requirement:

'This environment is tough; people expect things, so even if you are working flexible work hours or flexi location, you have to be responding all the time. Connectivity helps me send a reply, if not that night then early the next morning.'

(Participant 6)

TABLE 3: Requirements for the effective use of flexitime.

\begin{tabular}{ll}
\hline Subthemes & Associated meaning and explanation \\
\hline Critical resources & - resources, like 3 G and cellphones, are needed \\
to ensure connectivity and access to employees \\
at all times \\
- support staff is needed to assist all employees. \\
- employees should plan and manage their \\
Individual planning and \\
morking times, schedules and days to manage \\
work and nonwork responsibilities (by using, \\
for example, a personal diary or organiser to \\
manage time and ensure they meet objectives) \\
- continuous and advanced communication \\
between employees, clients, colleagues and \\
teams is necessary \\
- continuous and advanced management of \\
working schedules or hours, work locations, \\
work progress, expected dates for completion of \\
work and availability of employees is necessary \\
- employees should show accountability, \\
responsibility, maturity and motivation towards \\
the organisation and their work as well as in \\
how they use flexitime \\
- employees should be committed to achieving \\
deadlines, completing the required work, \\
working the correct number of hours as well as \\
satisfying client needs and expectations \\
- good and trusting relationships between \\
employees, managers and colleagues are \\
necessary \\
- guidance to employees about scheduling \\
working times and arrangements are necessary \\
- colleagues, managers and clients require \\
employees to be available and visible for \\
mentoring and transferring knowledge in the \\
organisation
\end{tabular}


Participants also emphasised the need for individual planning and management consistently in their responses. The participants gave personal examples of when they had failed to plan and manage their schedules effectively and of the consequences they faced. Some of the participants described failing to plan as being disrespectful towards colleagues, clients and managers who are likely to be affected. Consequently, participants in managerial roles emphasised professional discipline often. They described demonstrating qualities like maturity and responsibility as necessary for employee access and use of flexitime. The quotation below illustrates this:

'You need to own it, just because you are on flexitime don't make it anyone else's problem. You need to be responsible and professional in your use. If you go to lunch put your phone on forward and follow up on the calls, be responsible.'

(Participant 14)

Professional discipline links to job performance, which all participants emphasised with equal fervour. Participants agreed that employees should not use flexitime if it negatively affects their performance:

'If you do not complete what you need to it will affect other employees and the service lines within the organisation, our clients, targets and deadlines, so you have to be respectful of that.'

(Participant 12)

Participants also raised reduced job performance as a concern for managers. They mentioned that some managers seem to distrust employees' use of flexitime and consequently supported it less. Many participants described managers' trust in employees as a critical determiner of employee access to, and use of, flexitime.

Participants, who felt that scheduling or planning boards were necessary for managing and scheduling work tasks and as a way of notifying colleagues when they were working different hours or from different locations, recommended that the organisation use these boards for communication. This communication is critical to inform others when an employee is not available so that others can be on standby to assist.

Participants emphasised employee availability and visibility as essential for transferring knowledge, developing supportive relationships, mentoring junior employees and for planning and using flexitime successfully. The quotation below expresses these sentiments:

'Employees need to have access to more senior employees; they need to know who they are and build relationships with them. This will help them grow and develop to their best potential.'

(Participant 10)

Participants with children highlighted the importance of having flexible support at home. They should be able to adjust to employees' changing work schedules, especially when client deadlines and demands change so easily:

'Sometimes you have many client deadlines, you have to be flexible and so does your support at home because you cannot get rigid in terms of your professional capacity. So you need to be flexible and make sure your support structure at home fits that model.'

(Participant 9)
Central to controlling and measuring flexitime was the expressed need for the careful recording and scheduling of how employees use flexitime. Participants made several requests for guidelines and a company disciplinary process for those who misuse flexitime. Misuse of this nature is a serious concern for the organisation and managers, especially because they associate the misuse of flexitime with junior employees. Participants said that managers need to have more control and be able measure how employees use flexitime. The quotations that follow emphasise this clearly:

'Some rules or guidelines should be established to help managers; there should also be some kind of criteria to explain why some people get flexitime and others don't, just to make it fair.'

(Participant 14)

'When you notice they are abusing it, which happens you must address it quickly and disciplinary processes must be followed.'

(Participant 7)

Participants, who are frustrated because managers do not support their use of flexitime, said they needed managers to understand employees' unique lifestyles and daily challenges about their working preferences and to allow them the access to, and use of, flexitime that they require. Participants also mentioned their need to understand the guidelines for using flexitime, the criteria to qualify for flexitime as well as expectations about employee performance and use of flexitime. The quotations below illustrate this need to understand these aspects of flexitime:

'As a manager, you need to know who your employees are and what is their working preference, much like you need to know their strengths and weaknesses.'

(Participant 7)

'Education is necessary, particularly since several old-school managers don't recognise the benefits or know how to manage its use, so they just refuse employee use who lose out.'

(Participant 5)

Not all of the required aspects the participants referred were in use at the time of the interviews. Nevertheless, the participants emphasised their importance. Although participants mentioned several challenges and aspects that needed attention, they did indicate that benefits would follow if the organisation were to introduce flexitime and use it effectively.

\section{Theme 4: Benefits that would follow the use of flexitime}

Table 4 gives the various individual and organisational benefits participants mentioned.

\section{Individual benefits}

Managing responsibilities in personal life and controlling work were benefits the participants mentioned consistently in the interviews. Participants experienced work-life balance because of their newly found feeling of control and freedom to spend time at their own discretion, rather than feeling anxious about leaving the office: 
TABLE 4: Benefits that would follow the use of flexitime.

\begin{tabular}{ll}
\hline Subtheme & Associated meaning and explanation \\
\hline Individual benefits & - employees' freedom to attend to and manage \\
Ability to manage & personal responsibilities, commitments and \\
responsibilities in personal life & appointments \\
Ability to control work & - structure and management of working hours to \\
& suit employees' responsibilities, preferences, \\
& workloads and deadlines \\
Experience work-life balance & $\begin{array}{l}\text { - time for relaxation, exercise, study, family and } \\
\text { domestic responsibilities and social activities }\end{array}$ \\
Traffic management & - ability to avoid peak traffic periods \\
- less time spent or wasted in traffic & - reduced anxiety and stress \\
Psychological benefits & increased happiness, passion, energy, enjoyment \\
& and gratitude
\end{tabular}

'There is no feeling of anxiousness that you have to be at work, you cannot schedule a personal appointment, you know that if you have to step out to go see your specialist or go get medicine that it is not going to be frowned upon like.'

(Participant 4)

Participants went into detail when describing their psychological benefits. These benefits included reduced levels of stress and anxiety and increased levels of energy, passion and overall happiness in their working environment. According to the participants, all these benefits resulted from a better work-life balance.

Participants mentioned achieving bonuses or performance incentives as benefits of the improved productivity that results from flexitime. Participants felt they were achieving more because they could control their work according to their unique working preferences. Examples they gave are working early in the morning or at home to reduce distractions and interruptions. In addition, participants stated that flexitime allowed them to maintain productivity by making up for lost time because of examinations or illness. Many of the participants mentioned that avoiding peak traffic periods optimises production. They mentioned that many employees had arranged their working hours to miss these times. The quotation below gives an example of the benefits they experienced from the new arrangement:

'There are distinct examples of improved productivity. An audit team in Midrand started work at six in the morning and then left at three because they were very early and were not stressed from traffic therefore they were more productive.'

(Participant 14)

\section{Organisational benefits}

The ability to be flexible in response to changing deadlines and workloads is critical in a demanding, client-orientated environment. Flexitime allows for this adaptability and assists the organisation to meet client deadlines and improve overall organisational productivity and performance:

'Because the needs of the client changes all the time you might be slow this week and have many deadlines the next. So you need to have that flexibility to meet the client's deadlines.'

(Participant 8)

Flexitime as an attraction and retention strategy was a recurring subtheme in participant responses. Several of the participants related cases where employees returned to the company primarily because of the 'privilege' of working flexitime. Other participants described flexitime as the reason they work at the organisation, stating they could not work and manage their personal lives without it. Several participants commented on flexitime as a marketing tool for the organisation:

'Flexitime makes the company attractive to the outside world; you would be surprised how many people are interested in working here just because of it alone.'

(Participant 7)

Many participants interpreted flexitime as an expression of organisational care and concern for the employee. Participants reported heightened levels of employee loyalty, commitment and motivation that resulted in improved productivity. Participants commented on their willingness to work overtime to meet deadlines and complete tasks, knowing they would be granted time off. Some participants declared their intention to work longer and harder in exchange for the care the organisation offers employees:

'If they are giving you that flexibility then I always feel I have to do all my work I can't not, they are being so nice to me how could I let them down by not finishing my work.'

(Participant 8)

In addition to employee loyalty, commitment and motivation, many participants stated that increased levels of employee concentration and energy contribute to improved productivity. It was interesting to note that some participants indicated that they use time off to relax, whilst others said they use it to start and complete additional work.

These findings show that participants had opposing views on productivity. The subtheme of maintaining productivity (a challenge in theme 1) is an example. It was clear from the data analysis that some participants really do feel that flexitime helps them to be more productive. However, maintaining productivity whilst working flexitime was challenging for others.

The researcher could not ignore these opposing views and included them. The researcher felt that other factors could possibly influence flexitime, like personality types, and might explain these opposing views. Some employees tend to 
procrastinate whilst working and flexitime will allow them to procrastinate more whilst working. However, flexitime will work for employees who are more conscientious. However, this view is the researcher's and participants did not offer this explanation explicitly.

\section{Discussion}

The aim of this article is to report on the challenges and benefits associated with implementing flexitime as a WLB policy in a South African organisation.

These findings give valuable information about how employees experience flexitime, since work-life balance and its associated organisational polices, like flexitime, have recently become an important area of research for human resource practitioners (Dancaster, 2006; Glynn, Steinberg \& McCartney, 2002; Kossek \& Ozeki, 1998; Reynolds, 1999; Sanichar, 2004). Because of the various organisational and employee benefits associated with WLB, the popularity and use of these policies (like flexitime) in organisations - both nationally and internationally - have increased (AppiahMfodwa et al., 2000; Mageni \& Slabbert, 2005). However, implementing these policies in organisations poses challenges for human resource practitioners and employees (Clutterbuck, 2003; Mayberry, 2006; Powers, 2004).

The researcher discovered that the participants found flexitime challenging. This is consistent with findings from previous research (Oke \& Idiagbon-Oke, 2007).

Some of the specific aspects that participants found challenging are maintaining their productivity, managing their time and struggling to find a balance between work and personal life. Although previous studies (Horwitz et al., 2000; Grainger \& Holt, 2005; Mageni \& Slabbert, 2005) have identified time management and maintaining productivity as challenges, the one of balancing work and personal life is interesting and contradictory.

The reason organisations introduce flexitime is to help employees achieve and sustain this balance. Participants explained this more clearly by referring to other challenges that they experience. They include the absence of infrastructure in alternative work locations and the difficulty of disengaging from work. Many participants, even though they have flexible work hours, struggle to disengage from work when they participate in other activities. As a result, they still find it difficult to balance work and personal life. This inability to disengage from work relates closely to the literature on recovery experiences (like mastery, control, psychological detachment and relaxation) and the need for recovery experiences in order to maintain WLB (Sonnentag \& Fritz, 2007).

In addition to the individual challenges, participants identified general challenges they face when they use flexitime. These challenges relate more to the organisation and originate there. Its human resource practitioners should address them at that level.
Some of these challenges are consistent with those previous studies have found. They include managing perceptions, employees' misuse of flexitime, ineffective communication between employees and differences in the nature of work (Akyeampong, 1993; Bianchi \& Milke, 2010; CIPD, 2000; Cooke, 2005; Oke \& Idiagbon-Oke, 2007).

Other challenges the participants mentioned are their partial understanding of flexitime, the availability of employees and maintaining productivity. Although they also mentioned maintaining productivity as an individual challenge, participants in management positions also indicated difficulty with managing the productivity and performance of their subordinates who use flexitime.

Interestingly, the present research revealed an additional perspective to the existing literature on flexitime. The participants indicated their specific requirements for using flexitime effectively. According to them, these aspects are critical for organisations that offer flexitime. Some of them include critical resources; individual planning and management; job performance; professional discipline; effective communication; supportive relationships; and employee availability. Of these, previous research (Mageni \& Slabbert, 2005; Oke \& Idiagbon-Oke, 2007) included critical resources, planning and self-management. From the participants' point of view, organisations need to consider and address all of these aspects when they introduce flexitime because these aspects could help employees deal with the challenges they face.

Although flexitime poses various challenges, participants also identified the benefits of flexitime. The literature covers some of them. They include WLB, managing traffic, productivity, attraction and retention (Cooke, 2005; Cooke, Zeytinoglu \& Mann, 2009; Richman et al., 2008).

In addition to these benefits, the participants also mentioned individual benefits. They include being able to manage responsibilities in their personal lives, being able to control their work, psychological benefits (like reduced anxiety and stress), as well as organisational benefits like employee performance, concentration, loyalty, motivation and commitment.

The participants did indicate that their productivity and managing responsibilities in their personal lives improved. However, the recent literature is contradictory. Kattenbach, Demerouti and Nachreiner (2010) found no relationship between flexitime and performance. However, Carlson et al. (2010) found a full mediating relationship between family performance, job satisfaction and flexibility.

\section{Limitations of the study}

The present research yielded valuable information about flexitime and its implementation. However, it also has some limitations.

One major limitation is its research field - the organisation the researcher used in this research and its policy of flexitime. 
The present research field included only one organisation. This might suggest that the specific problems this research identified about implementing flexitime might be organisation-specific. If the researcher had included more than one organisation, she might have identified broader aspects or challenges. However, previous studies identified some of these themes and could reveal similar findings.

Although the researcher gave very valuable feedback to the organisation she used for this research, one should be careful about generalising the findings to flexitime policies that other organisations use or develop.

The researcher chose a non-random sample. However, it is worth mentioning that all the participants in the sample indicated that they have a domestic helper. This could explain some of the findings about their experiences of work-life balance or their use of flexitime. However, the participants did not explicitly mention this possible influence on their experiences of WLB or their use of flexitime. It also did not emerge during the interviews.

In addition, it is also important to consider the limitations of qualitative research. Qualitative research tends to work with smaller samples. This means that, although one can make valuable insights into particular cases, it is not possible to make claims about trends, regularities or distributions for a whole population (Willig, 2008).

Furthermore, because the objectivity of the researcher is more of an ideal than a reality, alternative interpretations of the data are always possible. Although a qualitative approach was appropriate for this research, it is always important to note that qualitative research does not always yield generalisable results.

\section{Recommendations}

Despite these limitations, this research will help human resource practitioners to develop and manage flexitime in their organisations.

This research clearly shows that organisations should attend to or manage various aspects of flexitime.

For example, the researcher recommends that, irrespective of the organisation and its specific flexitime policy, the employees' awareness and knowledge of, and information about, its policy is crucial. Therefore, human resource practitioners should inform their employees about the policy. They could do so during orientation programmes for new employees.

The researcher also recommends that organisations empower their employees to use these policies by giving them the necessary critical resources (like 3G and cellphones) and help them with infrastructure at alternative locations.

Furthermore, employees and employers should decide jointly on a way of managing and controlling the misuse of flexitime.
Important recommendations for future research include investigating the use of flexitime in different occupational, ethnic and gender groups and the effectiveness of implementing these policies.

In addition, future research could identify and evaluate other WLB policies that organisations in South Africa use.

\section{Conclusion}

This research makes it clear that implementing flexitime presents various challenges and organisations need to look at various aspects to use it effectively. Although employees are also responsible for improving the implementation of these policies, the main responsibility lies with organisations because many of the challenges occur at that level.

The effective use of flexitime policies depends largely on human resource practitioners' ability to address these challenges.

\section{Acknowledgements Authors' contributions}

The first author wrote and prepared most of the article and collected the data.

The second author gave guidance about the format and content of the article. She also helped with the technical preparation of the manuscript, the data analysis and the conceptualisation of the study.

\section{References}

Appiah-Mfodwa, A., Horwitz, F., Kieswetter, G., King, D., \& Solai, L. (2000). Flexible work practices, productivity improvement and employment. Society in Transition, 31(2), 95-110.

Akyeampong, E.B. (1993). Flexitime Work Arrangements. Perspectives on Labour and Income, 3(5), 123-142.

Allen, T.D., Herst, D.E., Bruck, C.S., \& Sutton, M. (2000). Consequences associated with work-to-family conflict: A review and agenda for future research. Journa of Occupational Health Psychology, 5, 278-308. doi:10.1037/1076-8998.5.2.278, PMid:10784291

Appleton, J.V. (1995). Analysing qualitative interview data: Addressing issues of validity and reliability. Journal of Advanced Nursing, 22, 993-997. doi:10.1111/j.1365-2648.1995.tb02653.x

Barling, J., \& Barenbrug, A. (1984). Some personal consequences of flexitime work schedules. Journal of Social Psychology, 7(4), 137-138. doi:10.1080/00224545.1 984.9924524

Bester, P. (2010, August 10). Qualitative research. Presented for the Research Methodology course at the North-West University, Potchefstroom, South Africa.

Blyton, P., Blunsdon, B., Reed, K., \& Datmalchian, A. (2006). Work-Life Integration: International perspectives on the balancing of multiple roles. New York: Palgrave MacMillan.

Bianchi, S.M., \& Milkie, M.A. (2010). Work and family research in the first decade of the 21st Century. Journal of Marriage and Family, 72(1), 705-725. doi:10.1111/ j.1741-3737.2010.00726.x

Burns, N., \& Grove, S.K. (1997). The practice of nursing research: Conduct, critique and utilization. (3rd edn.). Philadelphia, PA: WB Saunders.

Carlson, D.S., Grywacz, J.G., \& Kacmar, K.M. (2010). The relationship of schedule flexibility and outcomes via the work-family interface. Journal of Managerial Psychology, 25(4), 330-335. doi:10.1108/02683941011035278

Castells, M. (2000). Materials for an Exploratory Theory of the Networked Society. British Journal of Sociology, 51(2), 5-24. doi:10.1111/j.1468-4446.2000.00005.x, doi:10.1080/000713100358408

CIPD Research Report. (2000). Employment Trends Survey: People Driving Performance. London: Pertemps and Confederation of British Industry.

Clutterbuck, D. (2003). Managing Work-life Balance: A guide for HR in achieving organisational and individual change. London: UK Chartered Institute of Personnel and Development.

Cooke, G.B. (2005). The Nature and Incidents of Non-Standard Work Arrangements. Unpublished master's dissertation, McMaster University, Ontario, Canada. 
Cooke, G.B., Zeytinoglu, I.U., \& Mann, S.L. (2009). Weekend-based short work weeks: Peripheral work or facilitating 'work-life balance?'. Community, Work and Family, 12(4), 409-415. doi:10.1080/13668800902753911, PMid:2576907

Dancaster, L. (2006). Work-Life Balance and the legal right to request flexible working arrangements. South African Journal of Economic and Management Sciences, 9(2), 175-180.

De Vos, A.S., Strydom, H., Fouche, C.B., \& Delport, C.S.L. (2005). Research at Grass roots: For the social sciences and human service professions. Pretoria: Van Schaik Publishers.

Dex, S. (2004 July). Flexible Working Arrangements in the UK. Paper presented at the Work Life Balance Across the Life Course Conference, Centre for Research on Work Life Balance Across the Life Course Conference, Centre
Families and Relationships, Edinburgh: Edinburgh University.

Dalcos, S.M., \& Daley, D. (2009). Work pressure, workplace social resources and work-family conflict: The tale of two sectors. International Journal of Stress Management, 16(4), 291-311. doi:10.1037/a0017319

Doherty, L. (2004). Work-life balance initiatives: Implications for women. Employee Relations, 26(4), 433-452. doi:10.1108/01425450410544524

Duxbury, L., \& Higgins, C. (2003). Work-life conflict in Canada in the new millennium: A status report. Healthy Communities Division, Health Canada. Retrieved November 01, 2006, from http://www.cprn.org

Ferber, M.A., O'Farrell, B., \& Allen, L.R. (Eds.). (1991). Work and family: Policies for a changing work force. Washington, DC: National Academy Press.

Felstead, A., Jewson, N., Phizacklea, A., \& Walters, S. (2002). Opportunities to work at home in the context of work-life balance. Human Resource Management Journal, 12(1), 54-77. doi:10.1111/j.1748-8583.2002.tb00057.x

Forrester, M.A. (2010). Doing qualitative research in psychology. A practical guide. University of Kent: Sage.

Fox, M.L., \& Dwyer, D.J. (1999). An investigation into the effects of time and involvement in the relationship between stressors and work family conflict. Journal of occupational health psychology, 4(2), 167-174. doi:10.1037/10768998.4.2.164, PMid:10212868

Frone, M.R., Russel, M., \& Cooper, M.L. (1993). Relationship of work-family conflict, gender and alcohol expectations to alcohol use and abuse. Journal of Organizational Behaviour, 14(2), 545-558. doi:10.1002/job.4030140604

Galinsky, E., Bond, J.T., \& Hill, E.J. (2004). When Work Works: A status report on the workplace and flexibility. New York: Families and Work Institute.

Geurts, S.A.E., Rutte, C.G., \& Peeters, M.C.W. (1999). Antecedents and consequences of work-home interference among medical residents. Social Science \& Medicine, of work-home interference among medical residents.
$48,1135-1148$. doi:10.1016/S0277-9536(98)00425-0

Glynn, C., Steinberg, I., \& McCartney, C. (2002). Work-life balance: The role of the manager. Horsham: Roffey Park Institute.

Grainger, H., \& Holt, H. (2005). Results of the Second Flexible Working Employee Survey. Labour Market Trends, July, 297-302.

Greef, A., \& Nel, P.S. (2003). Employment transformation enhancement in South Africa: Establishing a job-sharing model to promote employment equity. South Africa: Establishing a job-sharing model to prom
African Journal of Labour Relations, 27(2), 23-62.

Guba, E.G. (1981). Criteria for assessing the trustworthiness of naturalistic inquiries. Educational Resources Information Centre Annual Review Paper, 29, 75-91.

Guba, E.G., \& Lincoln, Y.S. (1994). Competing paradigms in qualitative research. In N.K. Denzin \& Y.S. Lincoln (Ed.), Handbook of qualitative research (pp. 105-117) Thousand Oaks, CA: Sage.

Halpern, D.F. (2005). How time-flexible work policies can reduce stress, improve health and save money. Journal of the International Society for the investigation of Stress, 21(3), 157-168.

Hammersley, M. (1998). Reading ethnographic research. London: Longman.

Hayman, J.R. (2009). Flexible Work Arrangements: Exploring the linkages between perceived usability of flexible work schedules and work/life balance. Community, Work and Family, 12(3), 237-338. doi:10.1080/13668800902966331, PMid:2576907

Hesse-Biber, S.N., \& Leavy, P. (2004). Approaches to qualitative Research: A reader on theory and Practice. USA: Oxford University Press.

Hill, E.J., Erickson, J.J., Holmes, E.K., \& Ferris, M. (2010). Workplace flexibility, work hours and work-life conflict: Finding an extra day or two. Journal of Family Psychology, 24(3), 349-358. doi:10.1037/a0019282, PMid:20545408

Hobsor, C.J., Delunas, L., \& Kelsic, D. (2001). Compelling evidence for the Need for Corporate Work/Life Balance Initiatives: Results from a national survey of stressfu life-events. Journal of Employment Counseling, 4(8), 38-44.

Horwitz, F.M., Allan, C., Brosnan, P., \& Walsh, P. (2000). Flexible work practices: Perspectives from the Southern hemisphere. South African Journal of Business Management, 31(2), 76-83.

Horwitz, F., Kieswetter, G., King, D., \& Solai, L. (2000). Flexible Work Practices, Productivity Improvement and Employment. Journal of Management, 31(2), 95-110.

Hsieh, H., \& Shannon, S.E. (2005). Three approaches to qualitative content analysis Qualitative Health Research, 15, 1277-1288. doi:10.1177/1049732305276687, PMid:16204405

Kattenbach, R., Demerouti, E., \& Nachreiner, F. (2010). Flexible working times: Effects on employee exhaustion, work-nonwork conflict and job performance. Caree Development International, 15(3), 279-295. doi:10.1108/13620431011053749

Koekemoer, F.E., \& Mostert, K. (2006). Job characteristics, burnout and negative workhome interference. SA Journal of Industrial Psychology/SA Tydskrif vir workhome interference. SA
Bedryfsielkunde, 32(3), 87-97.

Koekemoer, E., \& Mostert, K. (2010a). An exploratory study of the interaction between Industrial Psychology/SA Tydskrif vir Bedryfsielkunde, 36(1), 1-15.
Koekemoer, E., \& Mostert, K. (2010b). Work-nonwork interference: Preliminary results on the psychometric properties of a new instrument. SA Journal of Industrial Psychology/SA Tydskrif vir Bedryfsielkunde, 36(1), 1-13. doi:10.4102/ sajip.v36i1.908

Koekemoer, E., Mostert, K., \& Rothman, S. Jr. (2010). Interference between work and nonwork roles: The development of a new South African instrument. SA Journal of Industrial Psychology/SA Tydskrif vir Bedryfsielkunde, 36(1), 1-14.

Kossek, E.E., \& Ozeki, C. (1998). Work-family conflict, policies, and the job-life satisfaction relationship: A review and directions for organizational behaviour - human resources research. Journal of Applied Psychology, 83, 139-149. doi:10.1037/0021-9010.83.2.139

Lewis, S., \& Cooper, C. (2005). Work-Life Integration: Case studies of organisational change. England: John Wiley and Sons.

Lewis-Beck, M.S., Bryman, A., \& Liao, T.F. (2004). The sage encyclopedia of socia science research methods. Thousand Oaks: Sage Publications.

Lyons, E. (2007). Doing qualitative research: Initial questions. In E. Lyons \& A. Coyle (Eds.), Analysing qualitative data in psychology. London: Sage Publications.

Mageni, G.F., \& Slabbert, A.D. (2005). Meeting the challenge of the work-life balance in the South African workplace. South African Journal Economic Management Sciences, 8(4), 393-401.

Marais, C., Mostert, K., Geurts, S.A.E., \& Taris, T.W. (2009). Measuring work-home interaction in indigenous languages: The psychometric properties of a translated version of the Survey Work-Home Interaction-Nijmegen (SWING) instrument South African Journal of Psychology, 39(2), 202-219.

Mayberry, P. (2006). Work-life balance policies and practices in the UK: Views of an HR practitioner. Journal of Management, 23(2), 167-188.

McDonald, P., Bradley, L., \& Brown, K. (2008). Visibility in the workplace: Still an essential ingredient for career success?. The International Journal of Human Resource Management, 19(12), 2198-2215. doi:10.1080/09585190802479447

Michie, S., \& Williams, S. (2003). Reducing work related psychological ill health and sickness absence: A systematic literature review. Occupational and Environmental
Medicine, 60(1), 3-9. doi:10.1136/oem.60.1.3, PMid:12499449, PMCid:1740370

Morehead, A. (2002). Behind the paid working of single mothers: Managing change and constructing support. Family Matters, 61(4), 56-61.

Morgan, L. (2009). The impact of work life balance and family friendly human resource policies on employees job satisfaction. London: Oxford University Press.

Mostert, K., \& Rathbone, A.D. (2007). Work characteristics, work-home interaction and engagement of employees in the mining industry. Management Dynamics, 16(2), 36-52.

Mostert, K., Cronjé, S., \& Pienaar, J. (2006). Job resources, work engagement and the mediating role of positive work-home interaction of police officers in the North West Province. Acta Criminologica, 19(3), 64-87.

Neuman, W.L. (2003). Social research methods: Qualitative and quantitative approaches. United States of America: Allyn and Bacon.

Oke, A., \& Idiagbon-Oke, M. (2007). Implementing flexible labour strategies: Challenges and key success factors. Journal of Change Management, 7, 69-87. doi:10.1080/14697010701254912

Patel, C.J., Govender, V., Paruk, Z., \& Ramgoon, S. (2006). Working mothers: Workfamily conflict, job performance and family/work variables. SA Journal of Industrial Psychology/SA Tydskrif vir Bedryfsielkunde, 32(2), 39-45.

Pieterse, M., \& Mostert, K. (2005). Measuring the work-home interface: Validation of the Survey Work-Home Interaction - Nijmegen (SWING) Instrument. Management Dynamics, 14(2), 2-15. Powers, V. (2004). Keeping Work and life in balance. Management Journal, 12(2),
45-59.

Reynolds, H.B. (1999). It is not enough to offer work/life programs - you need to promote them. Benefits Quarterly, Second Quarter, 13-17.

Rice, R., Frone, M.R., \& McFarlin, D.B. (1992). Work non-work conflict and the perceived quality of life. Journal of Organisational Behaviour, 13(2), 155-168. doi:10.1002/job.4030130205

Richman, A.L., Civian, J.T., Shannon, L.L., Hill, E.J., \& Brennan, R.T. (2008). The relationship of perceived flexibility, supportive work-life policies, and use of formal flexible arrangements and occasional flexibility to employee engagement and expected retention. Community, Work \& Family, 11(2), 183-197. doi:10.1080/13668800802050350, PMid:2576907

Ritchie, J., \& Lewis, J. (2005). Qualitative research practice: A guide for social science students and researchers. London: Sage Publications Ltd.

Robbins, S.P., Ordendaal, A., \& Roodt, G. (2004). Organisational Behaviour: Global and Southern African perspectives. Pretoria: Pearson Publications.

Roffey Park Institute (2004). Retrieved September 22, 2010, from http://www. roffeypark.com/research/wlb.html

Rost, l., \& Mostert, K. (2007). The interaction between work and home of employees in the earthmoving equipment industry: Measurement and prevalence. SA Journal of Industrial Psychology/SA Tydskrif vir Bedryfsielkunde, 33(2), 54-61.

Sanichar, A. (2004). The strategic implications and management considerations of work/life programmes. Journal of Contemporary Management, 1, 31-44.

Sonnentag, S., \& Fritz, C. (2007). The recovery experience questionnaire: Development and validation of a measure assessing recuperation and unwinding at work. 8998.12.3.204, PMid:17638488

Terre Blanche, M., Durrheim, K., \& Painter, D. (2006). Research in Practice: Applied methods for the social sciences. Cape Town: University of Cape Town Press.

Willig, C. (2008). Introducing qualitative research in Psychology. New York: Open University Press.

White, M., Hill, S., McGovern, P., Mills, C., \& Smeaton, D. (2003). High Performance Management Practices, working house and work life balance. British Journal of Industrial Relations, 41(5), 175-195. doi:10.1111/1467-8543.00268 